\title{
Commentary \\ Integrating student-centred learning in Asia-Pacific
}

\begin{abstract}
AABSIRACI
Universities are ideally placed to support the developing media industry in the Asia-Pacific by integrating their student projects with community service activities. Particular opportunities exist to support the mission of media industry support organisations by using the worldwide web as a platform for information dissemination, training and campaigning. The benefits for the media partner, the academy and the students are considerable. This article presents a successful model in East Timor and Melanesia that may be adapted in other tertiary institutions.
\end{abstract}

\section{SHARON TICKLE}

Queensland University of Technology

HIS article aims to summarise and present the current thinking by the
project leader about two recent university-industry partnership projects, one completed in East Timor in January 2003 and one which is only one-third of the way through in Melanesia. It is hoped that these two projects can serve as a model for integrating student learning and community out reach by the academy to the media profession in order to support sustainable capacitybuilding in the Pacific.

Following the success of the East Timor Press Web Project www.easttimorpress.com, which was an industry partnership between Creative Industries Faculty, Queensland University of Technology (QUT) and The Timor Post newspaper in Dili, East Timor, the author was approached by a member of the Media Council of Papua New Guinea to develop a corporate web site for the Media Council that could be shared with the revitalised Media 
Association of the Solomon Islands (MASI). This would be the second 'proof of concept' of running a web development project as a supervised student project and subsequently accessing QUT community service funds to support the handover and training of the partners' staff. Thus www.PNG-SImediacouncil.org was created. At the time of the project's inception both Papua New Guinea and the Solomon Islands were experiencing continuing difficulties in running their news media organisations free from governmental and other pressures and in training their dispersed staffs.

The project's goals are to:

- Develop, as part of QUT's commitment to international community service, a web presence for the Papua New Guinea and Solomon Islands media industry bodies to disseminate information about their activities, including journalism training, and to support their campaigns for a responsible, active and independent media that promotes informed participation by the citizens of PNG and the Solomon Islands.

- Train the PNG Media Council and MASI staff in web content management so that they would be able to train others.

- Internationalise the Creative Industries Faculty curriculum

- Promote interdisciplinary teaching and learning experiences for staff and students.

- Help students and staff apply their learning and creativity to a 'real-world' international project.

- Provide opportunities for staff to publish project papers and reports through presentations at conferences and symposia.

- Create close working relationships with industry partners in the Asia Pacific region.

- Profile QUT's strengths in innovative website development.

At the time of writing a static beta version of the website has been developed: www.PNG-SImediacouncil.org/beta This will be further developed between July and November 2003 as a sophisticated PHP-based content management system.

\section{Schematic of project model}

The Media Council of PNG-MASI website project schematic involves the five interacting groups.

A. Central to the project is an interdisciplinary team of undergraduate students in their second or third year of degree studies, plus a few postgraduate students. 


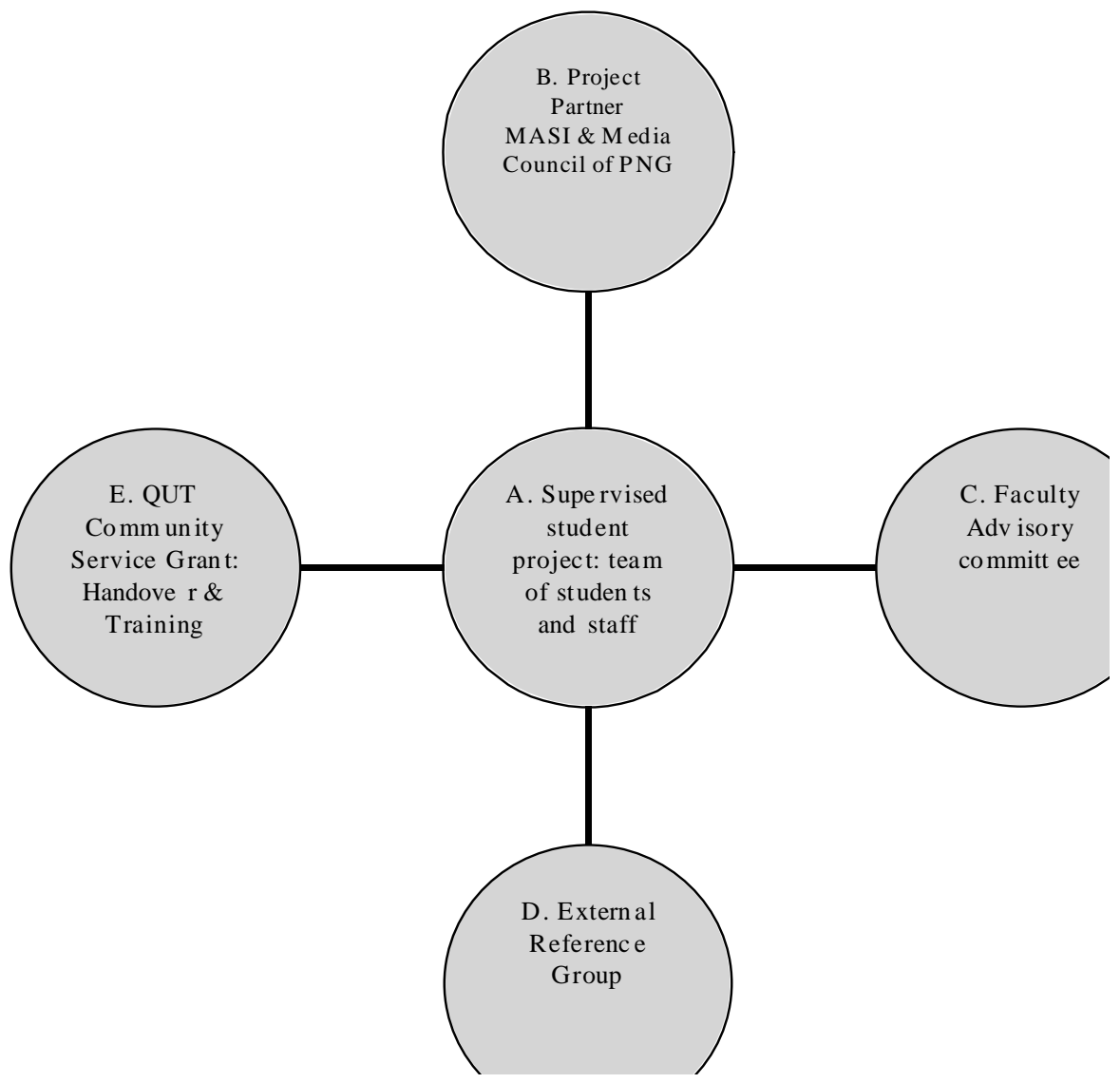

Students are drawn from journalism, communication design and media and communication disciplines. To be eligible, their grades must be at credit level or above. The optimal team size has been found to be between 12 and 17 . Students self-select to undertake the project as an elective subject and obtain the equivalent of one-quarter of a semester's credit upon completing prescribed learning tasks. The class meets weekly in the evening for three hours for 13 weeks during semester. This three-hour block is a combination of seminars and tutorials, as well as lab-based work during which students are actually designing and building the site.

Students apply for positions according to position descriptions written for the various roles within the six functional teams: phase 1 design/phase 2 
database programming, information architecture, writing and editing, research, documentation and training and marketing and public relations. Through a negotiated process that takes account of the students' abilities and learning goals that the students have articulated, staff appoint students to two positions on two different teams for the duration of the semester.

The scope of the MASI-SI web project includes:

1. An audit of relevant existing web-based resources and the telecommunications and information technology capacities of the target audiences

2. The design, drafting and development of the database-driven website www.PNG-SImediacouncil.org in consultation with the partners.

3. Hosting of the development site on QUT servers in 2003 and transfer of the site to a commercial server in 2004.

4. The development of copyright free training resources in English.

5. Training at QUT of PNG-SI staff to run the website.

6. Technical support for a further six months and evaluation and reporting of the project.

7. The production of supplementary promotional print materials about the organisations' activities and a website launch print publication.

8. Providing opportunities for enrolled students to engage positively with the South Pacific region and to learn specific knowledges and transferable skills in communications, website development and project management.

The project leader is also the subject coordinator (in this case a journalism staff member) and another casual staff member with the relevant experience is appointed as a senior tutor for the duration of the project. The staff member's time is accounted for in their workload and the cost of the casual staff appointment is paid for through student fees. The project is cost neutral to the faculty. In addition to dedicated staff, several academic staff from the advisory committee delivered relevant seminars in their area of expertise.

The East Timor Project ran over three semesters whereas the PNG-SI project will run over two semesters with the handover and training at the end of semester two (November 2003) and support and evaluation over the summer period.

B. The client and industry partners for the second project are the Media Association of the Solomon Islands (Solomon Star newspaper publisher John Lamani and Solomon Islands Broadcasting Corporation general manager Johnson Honimae) and the Media Association of Papua New Guinea. 
The Media Council of PNG's members are:

- The National newspaper (Ribunan Hijau group)

- The Post-Courier newspaper (News Ltd subsidiary)

- Word Publishing (publishers of Wantok and The Independent)

- EMTV, the national television service (Channel Nine, Australia)

- PNGFM, the Fiji-owned holding company of NAUFM, YUMIFM radio stations.

- National Broadcasting Corporation (NBC), the Government broadcaster.

- Advertising agencies

- Kalang Advertising, operators of FM100 radio station

- Hirad Ltd, holding company of FM Central and FM Morobe radio stations (non-financial members).

Communication with the client was initially through Bob Howarth, general manager of News Ltd's papers in Papua New Guinea (South Pacific Post Pty Ltd). Once the project was running, most communication was channelled through the presidents of the two media industry organisations or the secretariat, who consulted with their members when decisions needed to be made.

C. The Faculty Advisory Committee is comprised of academic staff from each of the disciplines whose students are undertaking the project plus computing support staff because this is a web-based project that requires IT support.

The FAC met several times during the initial stages of the project but communication after that was confined to email updates and email correspondence when decisions were needed.

D. The External Reference Group (ERG) is comprised of people with a range of expertise in the Asia Pacific region:

- Dr Max Quanchi, senior lecturer, School of Humanities and Human Services, QUT, South Pacific specialist

- Beris Gwynne executive director, Foundation for Development Cooperation www.fdc.org.au

- Barbara-Ann Butler, director of public affairs, Transparency International.

- Mark Otter, Solomon Islands specialist, University of Queensland. ${ }^{1}$

The ERG met once at the commencement of the project to give advice about the subject content and were contacted at various stages for input. Three 
members of the ERG gave seminars about their area of expertise.

\section{E. The Community Service Grant Scheme is administered at QUT through} the Division of Research and Advancement.

The scheme was devised to implement QUT's stated mission to use the resources and skills of QUT staff and students to service the community. As internationalisation of the degree curriculum, as well as community outreach, are also stated aims of QUT, the East Timor project was seen as a deserving project for funding. An application for funding for the third phase of the PNGSI website project, that is the handover and training of staff from MASI and the Media Council of PNG in Brisbane later this year, has been lodged.

The model described here has worked equally well for the partners, Creative Industries Faculty and for QUT. It meets the clients' need for a reliable, effective, no-cost presence on the web to allow them to fulfil their vital organisational goals and to have their staff trained at no expense. This is confirmed in this comment by MASI president Robert Iroga:

It's vital that we are linked on the net, for the betterment of our organisations and for their future.

This model meets the students' need to work on a real world project that 'makes a difference' and enables them to learn new skills and applies those they already have to a real world setting. Typical responses from students to a request for feedback about their experience of the project can be grouped under:

\section{Cultural understanding:}

At school my modern history teacher constantly told us how close and important Australia's relationship with Papua New Guinea and the Solomon Islands is. It was not really until this project that I realised the truth behind his statement, especially in relation to the turmoil in the Solomon Islands after the Townsville Peace Agreement.

And

This subject strengthened my knowledge of South Pacific cultures and societies and my understanding of the unique difficulties they face. 
Making a difference:

After studying journalism and public relations for three years I see the media as playing an extremely important part in society and feel strongly about the issue of media freedom. I saw our task as an important one, and through working on this project, not only have I had an enjoyable experience, but I also feel I have contributed to a worthwhile cause.

\section{Interdisciplinary relationship building:}

Sitting down with students from other disciplines to decide upon a common goal was quite exciting - it gave the subject life and inspired most of us to work beyond an 'adequate standard'.

\section{Engaging:}

KKB390 (this project) is definitely my best group experience in my time at university.

The model meets the academic and technical staff's professional and career needs to expand their professional knowledge across interdisciplinary boundaries, service their community of interest (the media) and be recognised for that effort. And finally it meets the faculty and QUT's need to internationalise the student and staff experience, showcase their students' talents and fulfil their social obligations.

\section{Note}

${ }^{1}$ Mark Otter is now the international programme director for the World Wildlife Fund.

Sharon Tickle is coordinator of international students and a lecturer in journalism in the Creative Industries Faculty at Queensland University of Technology. She was senior researcher for the first two phases of the awardwinning Public Journalism Project at QUT. Tickle presented an earlierversion of this paper, 'Online Journalism Capacity Building in East Timor', at the Journalism Education Association of New Zealand (Jeanz) annual conference at Whitireia Community Polytechnic, Porirua, on 28-29 November 2002. s.tickle@qut.edu.au 